\title{
Ukuran Perusahaan Sebagai Variabel Pemoderasi Pengaruh Profitabilitas Pada Penghindaran Pajak
}

\author{
Nyoman Trismana Putra ${ }^{1}$ \\ I Ketut Jati ${ }^{2}$ \\ ${ }^{1}$ Fakultas Ekonomi dan Bisnis Universitas Udayana (Unud), Bali, Indonesia \\ email: putratrismana@gmail.com / Telp: +62 81936633632 \\ ${ }^{2}$ Fakultas Ekonomi dan Bisnis Universitas Udayana (Unud), Bali, Indonesia
}

\begin{abstract}
ABSTRAK
Tujuan dilakukannya penelitian ini adalah untuk mengetahui pengaruh profitabilitas pada penghindaran pajak dengan ukuran perusahaan sebagai variabel pemoderasi. Penelitian ini dilaksanakan pada perusahaan manufaktur sektor industri barang konsumsi yang terdaftar di Bursa Efek Indonesia tahun 2014-2016. Jumlah sampel yang digunakan dalam penelitian ini sebanyak 25perusahaan dengan jumlah observasi 75 yang diperoleh dengan teknik non-probability sampling dengan metode purposive sampling. Teknik analisis data dilakukan dengan menggunakan teknik analisis moderatedregression analysis. Hasil penelitian yang dilakukan menunjukkan bahwa profitabilitas berpengaruh positif padapenghindaran pajak. Penelitian ini juga menemukan bahwa ukuran perusahaan memperlemah pengaruh profitabilitaspada penghindaran pajak.
\end{abstract}

Kata kunci : profitabilitas, ukuran perusahaan, penghindaran pajak

\begin{abstract}
The purpose of this study is to determine the effect of profitability on tax avoidance with the firm sizeas a moderator variable. This research was conducted at manufacturing companies in the consumer goods industry sector listed on the Indonesia Stock Exchange 2014-2016. The number of samples used in this study as many as 25 companies with 75 observations obtained with non-probability sampling technique with purposive sampling method. Data analysis technique is done by using analysis technique of moderated regression analysis. The results of the research show that profitability has a positive effect on tax avoidance. The study also found that firm size weakened the effect of profitability on tax avoidance.

Keyword : profitability, firm size, tax avoidance
\end{abstract}

\section{PENDAHULUAN}

Pajak adalah salah satu sumber penerimaan negara yang digunakan untuk melakukan pembangunan nasional guna mensejahterakan masyarakatnya. Pajak dibedakan menjadi dua macam, yaitu pajak negara dan pajak daerah. Salah satu jenis pajak negara adalah pajak penghasilan, dikenakan dari penghasilan yang didapatkan wajib pajak yang dalam penelitian ini wajib pajak badan sesuai dengan jenis usaha yang dilakukan wajib pajak tersebut sesuai dengan undang-undang 
perpajakan yang berlaku (Utari dan Supadmi, 2017). Mewujudkan kemakmuran rakyat memerlukan kontribusi wajib dan memaksa dari wajb pajak orang pribadi atau badan kepada negara namun tidak secara langsung dapat dimikmati oleh wajib pajak merupakan pengertian dari pajak.

Self assessment system merupakan sistem pemungutan pajak yang digunakan di Indonesia, self assessment system adalah suatu sistem pemungutan pajak yang memberikan wewenang penuh kepada Wajib Pajak untuk menghitung, memperhitungkan, menyetorkan, dan melaporkan sendiri besarnya utang pajak (Ilyas dan Burton, 2013:37).

Setiap tahun pemerintah selalu menaikkan target penerimaan negara dari sektor pajak, namun kenyataannya realisasi pajak yang diterima negara selalu lebih rendah dari yang sudah ditargetkan. Data dari liputan6.com, efektivitas dari pemungutan pajak yang dilakukan pemerintah terus mengalami penurunan dari tahun 2014 - 2016. Efektivitas pemungutan pajak di Indonesia dapat dilihat pada Tabel 1 berikut.

Tabel 1.

Efektivitas Pemungutan Pajak di Indonesia

\begin{tabular}{cccc}
\hline Tahun & Target & Realisasi & $\begin{array}{c}\text { Efektifitas } \\
\text { Pemungutan } \\
\text { Pajak }\end{array}$ \\
\hline 2014 & 1.246 Triliun & 1.143 Triliun & $91,75 \%$ \\
2015 & 1.294 Triliun & 1.060 Triliun & $81,91 \%$ \\
2016 & 1.355 Triliun & 1.105 Triliun & $81.54 \%$ \\
\hline
\end{tabular}

Sumber: www.liputan6.com, 2018

Dapat dilihat pada Tabel 1 bahwa efektivitas penerimaan pajak tiap tahunnya dari tahun 2014 - 2016 mengalami penurunan. Besarnya efektivitas penerimaan pajak pada tahun 2014 sebesar 91,75\%, 2015 sebesar 81,91\%, dan 
pada tahun 2016 sebesar 81,54\%. Penerimaan pajak yang tidak sesuai dengan target yang telah ditetapkan tersebut bisa disebabkan oleh salah satunya adalah adanya praktik penghindaran pajak yang dilakukan oleh wajib pajak (Dharma dan Ardiana, 2016). Penghindaran pajak bisa terjadi karena pada intinya pemengang saham di tiap perusahaan tentu ingin mendapatkan return yang tinggi karena sudah menanamkan modalnya di perusahaan tersebut, dengan mengurangi jumlah pajak yang terutang, perusahaan bisa meningkatkan keuntungannya.

Pemungutan pajak merupakan hal yang sulit untuk dilakukan, dari sisi fiskus pajak merupakan salah satu sumber pendapatan yang secara potensial dapat mempengaruhi dan meningkatkan penerimaan negara, sedangkan dari sisi perusahaan pajak akan mejadi beban yang akan menurunkan laba perusahaan sehingga perusahaan perlu mempertimbangkannya. Ada beberapa cara yang bisa perusahaan lakukan untuk mengindari besarnya pembayaran pajaknya, diantaranya penggelapan pajak (tax evasion) dan penghindaran pajak (tax avoidance). Menurut Kirchler, Maciejovsky, dan Schneider (2002), penghindaran pajak merupakan suatu carauntuk melakukan penurunan beban pajak dengan cara yang legal, contohnya mengambil keuntungan dari celah-celah kelemahan perundang-undangan perpajakan, sedangkan penggelapan pajak adalah suatu carapengurangan pajak dengan melakukan tindakan yang dilarang undangundang, misalnya melaporkan penghasilan tidak sesuai dengan yang sebenarya. Jacob (2014) mendefinisikan tax avoidance sebagai salah satu cara pengurangan pembayaran pajak atau meminimalkan beban pajak dengan caramengatur sedemikian rupa transaksi yang dilakukan agar memperoleh keuntungan dari 
kelemahan-kelemahan dalam peraturan pajak, seperti melakukan transaksi melalui transaksi yang bukan merupakan objek pajak. Dalam hal ini cara yang digunakan untuk mengukur penghindaran pajak adalah Effective Tax Rate (ETR).

Profitabilitas adalah salah satu faktor yang bisa menyebabkan terjadinya praktik penghindaran pajak yang dilakukan perusahaan. profiabilitas adalah salah satu pengukuran kinerja bagi perusahaan dalam kemampuannya menghasilkan laba selama periode tertentu. Keuntungan suatu perusahaan berpengaruh negatif dengan ETR karena jika suatu perusahaan semakin efisien, maka perusahaan tersebut akan memiliki beban pajak yang lebih rendah sehingga ETR perusahaan tersebut akan lebih rendah (Derashid dan Zhang, 2003). Profitabilitas terdiri dari beberapa rasio, dalam penelitian ini profitabilitas diproksikan dengan menggunakan Return On Asset (ROA). ROA adalah gambaran kinerja keuangan perusahaan dalam menghasilkan laba dari seberapa besar perusahaan menggunakan aset. Semakin besar rasio ROA, maka semakin besar laba yang dihasilkan perusahaan, ketika laba yang dihasilkan perusahaan membesar, maka beban pajak penghasilan akan semakin membesar seiring dengan meningkatnya laba perusahaan, maka kecenderungan perusahaan untuk melakukan praktik penghindaran pajak akan meningkat.

Fenomena yang terjadi tentang penghindaran pajak dapat ditemukan pada kasus Google. Google adalah sebuah perusahaan multinasional dari Amerika Serikat yang berkekhususan pada jasa dan produk internet. Seperti dilansir liputan6.com Google mendirikan induk usaha di Singapura yang tersohor sebagai negara surga pajak dengan tarif pajaknya yang rendah untuk menangani bisnisnya 
di ASIA termasuk Indonesia. Google merasatidak pernah ada Bentuk Usaha Tetap (BUT) di Indonesia karena faktanya seluruh kontrak dijalankan tanpa melalui kantor perwakilan di Negara ini, seluruh kontrak yang dilakukann Google dengan konsumen di Indonesia belangsung secara online. BUT merupakan satu syarat atau ambang batas suatu negara sumber penghasilan bisa memungut pajak. Tanpa BUT, tax treaty tidak berhak memajaki penghasilannya yang didapat dari iklan secara online.

Berdasarkan penelitian terdahulu mengenai pengaruh profitabilitas pada penghindaran pajak terdapat ketidak konsistenan hasil. Penelitian yang dilakukan Praditasari dan Setiawan (2017) menyatakan bahwa profitabilitas memiliki hubungan positif pada penghindaran pajak. Hasil yang sama juga dinyatakan oleh penelitian yang dilakukan oleh Dewinta dan Setiawan (2016), Dewi dan Noviari (2017), dan Darmawan dan Sukartha (2014) yang menghasilkan bukti empiris pengaruh positif profitabilitas pada penghindaran pajak. Penelitian yang dilakukan oleh Maharani dan Suardana (2014) menyatakan bahwa profitabilitas memiliki pengaruh negatif dengan penghindaran pajak. Hasil yang sama juga dinyatakan oleh penelitian yang dilakukan oleh Agusti (2014), Utari dan Supadmi (2017), Siregar dan Widyawati (2016) dan Saputra dkk (2015) yang menunjukkan hasil hubungan negatif profitabilitas dengan penghindaran pajak. Sedangkan penelitian yang dilakukan oleh Marfu'ah dkk (2015), Utami (2012), dan Cahyono dkk (2016) menyatakan bahwa profitabilitas tidak memiliki pengaruh pada penghindaran pajak. Rasio rata-rata profitabilitas perusahaan manufakur industri barang konsumsi yang diukur dengan menggunakan ROA mengalami fluktuasi 
dari tahun 2014 - 2016. Rasio profitabilitas perusahaan manufaktur industri barang kansumsi yang terdaftar di Bursa Efek Indonesia (BEI) dapat dilihat pada Tabel 2 berikut.

Tabel 2.

Rata-Rata Rasio Profitabilitas Perusahaan Manufaktur Sektor Industri Barang Konsumsi di BEI

\begin{tabular}{ccc}
\hline Tahun & Return On Asset & $\begin{array}{c}\text { Efektivitas } \\
\text { Penerimaan } \\
\text { Pajak }\end{array}$ \\
\hline 2014 & $12.33 \%$ & $91.74 \%$ \\
2015 & $12.08 \%$ & $81.91 \%$ \\
2016 & $12.71 \%$ & $81.54 \%$ \\
\hline
\end{tabular}

Sumber: Data Diolah, 2018

Data di atas menunjukan rasio profitabilitas perusahaan manufaktur sektor industri barang konsumsi yang diukur dengan menggunakan Return On Asset (ROA). Dapat dilihat bahwa dari tahun 2014 sampai dengan 2016, persentase rasio ROA mengalami fluktuasi tetapi efektivitas penerimaan pajak terus pengalami penurunan setiap tahunnya. Adanya ketidak konsistennya hasil penelitian sebelumnya terkait dengan pengaruh profitabilitas pada penghindaran pajak dan berflukuasinya rasio profitabilitas perusahaan mendorong penulis untuk menambahkan ukuran perusahaan sebagai variabel pemoderasi hubungan antara profitabilitas dengan penghindaran pajak, yang nantinya variabel pemoderasi ini dapat memperkuat ataupun memperlemah hubungan antara profitabilitas dengan penghindaran pajak pada perusahaan manufaktur sektor industri barang konsumsi yang terdaftar di Bursa Efek Indonesia Periode 2014-2016. Perusahaan yang besar kecenderungan mampu menghasilkan laba yang stabil, kemampuan dalam memperoleh laba yang lebih stabil cenderung dimiliki oleh perusahaan besar dibandingkan perusahaan yang berukuran kecil. Perusahaan yang besar juga 
ISSN: 2302-8556

E-Jurnal Akuntansi Universitas Udayana

Vol.25.2.November (2018): 1234-1257

cenderung memiliki sumber daya yang baik dalam melakukan pengelolaan pajaknya. Laba yang besar dan stabil ditambah dengan sumber daya yang dimiliki akan cenderung untuk perusahaan melakukan penghindaran pajak. Alasan pemilihan sektor industri barang konsumsi disebabkan perusahaan consumer god merupakan perusahaan yang tidak bisa dilepaskan dari kehidupan manusia, perusahaan ini terus mendapatkan tempat utama bagi para calon investor untuk menanamkan modalnya (Rezika, 2017). Perusahaan manufaktur juga dipilih karena merupakan perusahaan yang kegiatan usahanya lengkap mulai dari pembelian bahan baku, mengolahnya menjadi barang jadi hingga proses menjual kepasaran sehingga proses aktivitas usahanya sebagian besar menyangkut aspek perpajakan, Dewinta (2016). Selain itu dalam kurun waktu tahun 2008 sampai dengan tahun 2012, Direktorat Jendaral Pajak pernah memfokuskan perusahaan manufaktur sebagai wajib pajak untuk pemeriksaan (Mulyani, 2014).

Rumusan masalah dalam penelitian ini adalah apakah profitabilitas berpengaruh pada penghindaran pajak dan apakah ukuran perusahaan dapat memoderasi pengaruh profitabilitas pada penghindaran pajak. Tujuan dari penelitian ini adalah untuk memperoleh bukti empiris pengaruh profitabilitas pada penghindaran pajak, dan untuk memperoleh bukti empiris ukuran perusahaan dalam memoderasi pengaruh profitabilitas pada penghindaran pajak.

Ada dua landasan teori yang digunakan dalam penelitian ini, yang pertama yaitu teori agensi. Teori agensi merupakan konsep yang menjelaskan hubungan antara agent (manajemen suatu usaha) dan principal (pemilik usaha). Agent melakukan tugas-tugas tertentu yang diperuntukkan bagi principal dan principal 
bertugas untuk memberikan sebuah imbalan kepada agent (Hendriksen dan Breda, 1992). Jensen dan Meckling (1976) mendefinisikan hubungan keagenan sebagai kontrak antara satu orang atau lebih (pemberi kerja atau prinsipal) untuk melakukan sejumlah jasa dan memberikan wewenang dalam pengambilan keputusan kepada pihak lain (agen). Berdasarkan teori agensi, para agen akan berusaha untuk menaikkan laba perusahaan agar bisa mendapatkan imbalan yang lebih besar dari prinsipal. Teori lain yang digunakan dalam penelitian ini yaitu teori akuntansi positif, Teori akuntansi positif merupakan sebuah teori yang dikembangkan oleh Watts dan Zimmerman (1960) yang mengatakanuntuk tujuan yang menguntungkan pihak tertentu dapat mempengaruhi pemilihan kebijakan akuntansi dan praktiknya dalam perusahaan di masa yang akan datang. Teori akuntansi positif akan memperlihatkan kebijakan akuntansi yang telah dibuat demi manfaat bagi perusahaan, sehingga kebijakan dipilih mendapat pengaruh dari perhitungan yang dapat menguntungkan sebagian pihak. Berdasarkan teori akuntansi positif, sumber daya yang baik dapat dimanfaatkan oleh perusahaan untuk memaksimalkan kebijakan akuntansi yang dibuat untuk meminimalkan pembayaran pajak perusahaan.

Return On Asset (ROA) merupakan salah satu dari sekian banyak rasio profitabilitas. Rasio profitabilitas merupakan rasio yang paling disoroti dalam analisis laporan keuangan, karena tujuan utama perusahaan adalah hasil operasi/keuntungan dan rasio profitablitas mampu menujukkan kemampuan perusahaan dalam menghasilkan laba. ROA digunakan untuk melihat perusahaan dalam kemampuannya memperoleh keuntungan dari total aset yang dimilikinya. 
Semakin besar perolehan nilai ROA perusahaan maka akan semakin tinggi keuntungan yang dihasilkan perusahaan. hubungan positif dimiliki laba dengan beban pajak sehingga jika laba perusahaan yang diperoleh tinggi maka beban pajak juga akan ikut tinggi seiring dengan peningkatan laba perusahaan, sehingga sangat mungkin perusahaan berupaya menghindari peningkatan beban pajak yang dikenakan. Profitabilitas perusahaan memiliki hubungan yang positif dengan penghindaran pajak, apabila perusahaan menginginkan beban pajak yang tidak terlalu tinggi maka perusahaan harus efesien dari segi beban sehingga tidak perlu membayar pajak dalam jumlah yang besar (Surbakti, 2012). Penelitian yang dilakukan oleh Dewinta dan Setiawan (2016), Praditasari dan Setiawan (2017), Dewi dan Noviari (2017) dan Darmawan (2014) menyatakan bahwa profitabilitas berpengaruh positif pada penghindaran pajak. Berdasarkan uraian di atas, maka hipotesis pertama yang disusun peneliti adalah:

$\mathrm{H}_{1}$ : profitabilitas berpengaruh positif pada penghindaran pajak.

Ukuran perusahaan adalah suatu skala yang dapat mengklasifikasikan perusahaan menjadi perusahaan besar dan kecil menurut berbagai cara seperti total aktiva dan tingkat penjualan. Perusahaan yang masuk dalam kelompok perusahaan besar akan lebih bisa dalam menghasilkan laba dan stabil dibandingkan dengan perusahaan yang berukuran kecil. Keuntungan tinggi yang diperoleh akan menyebabkan kewajiban pajak yang ditanggung perusahaan membesar sehingga ada kecendrungan perusahaan melakukan praktik penghindaran pajak. Selain itu, perusahaan yang masuk kedalam kelompok besar juga cenderung memiliki sumber daya yang baik untuk mengelola beban 
pajaknya. Perusahaan yang berskala kecil cenderungmemiliki sumber daya manusia yang tidak memadai untuk memanfaat kelemahan pajak guna menghindari kewajiban pajak penghasilan tinggi yang akan ditanggung perusahaan (Nicodeme, 2007 dalam Darmadi 2013). Penelitian yang telah dilakukan oleh Swignly dan Sukartha (2015), Dharma dan Ardiana, (2016), Dewinta dan Setiawan (2016), dan Siregar (2016) menyatakan bahwa ukuran perusahaan berpengaruh positif pada penghindaran pajak. Berdasarkan uraian di atas, maka hipotesis yang diajukan adalah:

$\mathrm{H}_{2}$ : Ukuran perusahaan memperkuat pengaruh profitabilitas pada penghindaran pajak.

\section{METODE PENELITIAN}

Metode penelitian yang sesuai untuk analisis penelitian ini adalah pendekatan kuantitatif dengan bentuk asosiatif. Penelitian ini menjelaskan bagaimana hubungan variabel profitabilitas dengan penghindaran pajak dengan ukuran perusahaan sebagai variabel pemoderasi. Pada penelitian ini lokasi yang digunakan adalah pada perusahaan manufaktur sektor industri barang konsumsi yang terdafrtar di Bursa Efek Indonesia (BEI). Obyekyang menjadi kajian dalam penelitian iniadalahpenghindaran pajakyang dipengaruhi oleh profitabilitas, dan ukuran perusahaan.

Dalam penelitian ini variabel bebas yaitu profitabilitas diproksikan menggunakan ROA, Alasan menggunakan ROA karena perusahan dengan total aset yang besar cenderung memiliki sumber daya yang baik dalam mengelola aset yang dimilikinya, jadi semakin besar aset yang dimiliki perusahaan semakin 
efisien perusahaan mengelola asetnya yang cenderung mendapatkan laba yang lebih optimal. ROA dapat dirumuskan sebagai berikut.

$$
\mathrm{ROA}=\frac{\text { Laba Bersih Setelah Pajak }}{\text { Total Aset }} \times 100
$$

Variabel terikat dalam penelitian ini yaitu penghindaran pajak diproksikan melalui earning tax rate (ETR), ETR adalah perbandingan antara beban pajak yang ditanggung perusahaan dengan laba komersial sebelum pajak perusahaan (Richardson dan Lanis, 2007). Effective tax rate (ETR) digunakan untuk merefleksikan perbedaan antara perhitungan laba buku dengan laba fiskal (Frank et al, 2009). Menurut Hanlon dan Heintzman (2010) proksi effective tax rate mampu memperlihatkantax avoidance yang dilakukan perusahaan yang berasal dari dampak beda temporer dan memberikan gambaran menyeluruh menganai perubahan beban pajak karena mewakili pajak kini dan pajak tangguhan. ETR adalah total pajak yang dibayarkan dibagi dengan laba sebelum pajak. Rumus untuk menghitung ETR adalah sebagai berikut.

$$
\text { ETR }=\frac{\text { Beban Pajak Penghasilan }}{\text { Laba Sebelum Pajak }}
$$

Variabel moderasi yang digunakan dalam penelitian ini yaitu ukuran perusahaan diproksikan dengan log total aset, karena dinilai bahwa ukuran perusahaan ini mempunyai keunggulan dalam tingkat kestabilan dari periode ke periode berikutnya dibandingkan dengan proksi lainnyadibandingkan (Yogiyanto, 2007:282). Ukuran perusahaan menurut (Yogiyanto 2007:282) dihitung dengan cara sebagai berikut.

Ukuran perusahaan $=\log$ Total Aset 
Populasi dari penelitian ini adalah seluruh perusahaan manufaktur sektor industri barang konsumsi yang terdaftar di BEI selama tahun 2014-2016 yang berjumlah 36 perusahaan. Sampel dalam penelitian ini adalah perusahaan manufaktur yangterdaftar di BEI pada sektor industri barang konsumsi yang selama tahun 2014-2016. Penelitian ini menggunakan purposive sampling dalam penentuan sampelnya, dengan kriteria sebagai berikut: Perusahaan manufaktur sektor industri barang konsumsi yang menerbitkan laporan keuangan selama 2014-2016 dan telah diaudit, Perusahaan yang tidak mengalami kerugian selama periode 2014-2016.

Penelitian ini menggunakan metode observasi non participant dalam pengumpulan datanya, yaitu dengan mengumpulkan, membaca, mencatat datadata, keterangan, dan informasi dimana peneliti tidak secara langsung terlibat dan hanya sebagai pengamat independen (Sugiyono, 2014:204). Data yang dimaksudkan adalah data publikasi laporan keuangan tahunan perusahaan manufaktur sektor industri barang konsumsi yang telah terdaftar pada BEI dan sesuai dengan kriteria pemilihan sampel. Data kuantitatif dalam penelitian ini adalah angka-angka laporan keuangan perusahaan manufaktur sektor industri barang konsumsi yang terdaftar di BEI tahun 2014-2016, sedangkan daftar namanama perusahaan manufaktur sektor industri barang konsumsi yang terdaftar di BEI merupakan data kualitatif dalam penelitian ini . Hipotesis dalam penelitian ini diuji dengan menggunakan uji moderated regression analysis (MRA). Uji MRA merupakan aplikasi khusus linier berganda. MRA dalam persamaan regresinya mengandung interaksi, yaitu perkalian dua atau lebih variabel independen. MRA 
digunakan untuk menguji hubungan profitabilitas pada penghindaran pajak dimana ukuran perusahaan sebagai variabel pemoderasi. Persamaan regresi dari model regresi moderasi adalah:

$$
Y=\alpha+\beta_{1} X_{1}+\beta_{2} X_{2}+\beta_{3} X_{1} X_{2}+\mu
$$

Keterangan:

$$
\begin{array}{ll}
\mathrm{Y} & =\text { Penghindaran Pajak } \\
\mathrm{A} & =\text { konstanta } \\
\mathrm{X}_{1} & =\text { profitabilitas } \\
\mathrm{X}_{2} & =\text { ukuran perusahaan } \\
\beta_{1}-\beta_{3} & =\text { koefisien regresi } \\
\mathrm{X}_{1} \mathrm{X}_{2} & =\text { interaksi antara profitabilitas dengan ukuran perusahaan } \\
\mu & =\text { standard error }
\end{array}
$$

\section{HASIL DAN PEMBAHASAN}

Perusahaan yang digunakan dalam penelitian iniditentukan dengan cara penentuan sampel yaitu teknik purposive sampling sesuai dengan kriteria yang telah ditetapkan. Proses penyeleksian sampel dalam penelitian ini dapat dilihat pada Tabel 3 .

Tabel 3.

\section{Proses Seleksi Sampel}

\begin{tabular}{lc}
\hline \multicolumn{1}{c}{ Keterangan } & Jumlah \\
\hline $\begin{array}{l}\text { Perusahaan manufaktur sektor industri barang konsumsi yang } \\
\text { terdaftar di Bursa Efek Indonesia selama periode 2014-2016. }\end{array}$ & 36 \\
$\begin{array}{l}\text { Perusahaan manufaktur sektor industri barang konsumsi yang } \\
\text { menerbitkan laporan keuangan tidak berturut-turut selama 2014- }\end{array}$ & (3) \\
2016. & \\
$\begin{array}{l}\text { Perusahaan yang mengalami kerugian selama periode 2014- } \\
2016 .\end{array}$ & 25 \\
\hline Jumah perusahaan yang terpilih sebagai sampel & 75 \\
\hline Total sampel dalam tiga tahun penelitian &
\end{tabular}


Analisis statistik desktiptif adalah gambaran atau deskripsi data yang dilihat dari nilai maksimum, nilai minimum, nilai rata-rata (mean), dan standar deviasi. Pada sub-bab ini akan dibahas mengenai hasil pengujian statistik deskriptif pada masing-masing variabel yaitu variabel return on asset, ukuran perusahaan dan efective tax rates yang diperoleh dari hasil uji dengan SPSS. Hasil statistik deskriptif dari satu per satu variabel yang digunakan dalam penelitian ini dapat dlihat pada Tabel 4 .

\section{Tabel 4.}

Hasil Uji Statistik Deskriptif

\begin{tabular}{|c|c|c|c|c|c|}
\hline Variabel & $\mathbf{N}$ & Min. & Max. & Mean & $\begin{array}{c}\text { Std. } \\
\text { Deviasi }\end{array}$ \\
\hline Profitabilitas $\left(\mathrm{X}_{1}\right)$ & 75 & 0,002 & 0,432 & 0,124 & 0,099 \\
\hline Ukuran Perusahaan $\left(\mathrm{X}_{3}\right)$ & 75 & 20,715 & 32,151 & 28,286 & 2,249 \\
\hline Variabel & $\mathbf{N}$ & Min. & Max. & Mean & $\begin{array}{c}\text { Std. } \\
\text { Deviasi }\end{array}$ \\
\hline $\operatorname{ETR}(\mathrm{Y})$ & 75 & 0,066 & 0,430 & 0,257 & 0,054 \\
\hline
\end{tabular}

Berdasarkan Tabel 4 dapat dilihat bahwa tax avoidance yang diukur dengan menggunakan ETR pada perusahaan manufaktur sektor industri barang konsumsi yang terdaftar di BEI tahun 2014-2016 memiliki nilai rata-rata sebesar 0,257 lebih mendekati tarif dasar pajak penghasilan badan yang berlaku di Indonesia sebesar $25 \%$ yang mengindikasikan perusahaan melakukan praktik penghindaran pajak semakin kecil. Sebaran data tax avoidance memiliki kemerataan atau perbedaan data yang tidak mencolok sesuai dengan nilai standar deviasi yang diperoleh sebesar 0,054. Nilai terkecil rasio ETR sebesar 0,066 pada tahun 2015 yang dimilki oleh perusahaan Mandom Indonesia Tbk, sedangkan nilai tertinggi rasio ETR sebesar 0,43 pada tahun 2014 yang dimiliki oleh perusahaan Langgeng Makmur Industry Tbk. 
Variabel profitabilitas memiliki nilai mean sebesar 0,124. Ada kecenderungan nilai mean profitabilitas mendekati nilai minimumnya, hal ini mempunyai arti bahwa perusahaan memperoleh laba yang rendah dengan menggunakan total asset yang dimilikinya. Sebaran data variabel profitabilitas yang diproksikan melalui ROA memiliki kemerataan atau perbedaan data yang tidak mencolok sesuai dengan nilai standar deviasi yang diperoleh sebesar 0,099. Nilai terkecil rasio ROA sebesar 0,002 pada tahun 2014 yang dimiliki oleh perusahaan Langgeng Makmur Industry Tbk, sedangkan nilai tertiggi rasio ROA yang diperoleh sebesar 0,432 pada tahun 2016 yang dimiliki oleh Multi Bintang Indonesia Tbk.

Nilai rata-rata variabel ukuran perusahaan memiliki nilai sebesar 28,286 yang lebih mendekati nilai maksimum yang menandakan bahwa skala perusahaan manufaktur sektor industri barang konsumsi yang terdaftar di BEI cenderung perusahaan berskala besar. Nilai standar deviasi adalah sebesar 2,249 yang menunjukkan sebaran data ukuran perusahaan sudah merata atau perbedaan data satu dengan yang lainnya tidak tergolong tinggi. Perusahaan yang memiliki nilai ukuran perusahaan terkecil adalah Delta Djakarta Tbk sebesar 20,715 pada tahun observasi 2014. Perusahaan dengan nilai ukuran perusahaan terbesar adalah Indofood Sukses Makmur Tbk sebesar 32,151 pada tahun observasi 2015.

Suatu model regresi akan bisa dijadikan sebagai alat estimasi yang tidak bias jika data terdistribusi normal, tidak terjadi multikolinieritas, tidak terjadi heteroskedastisitas dan tidak terjadi autokorelasi. Untuk itu maka dilakukan uji model regresi harus dilakukan dengan pengujian asumsi klasik terhadap model 
regresi yang akan digunakan. Uji asumsi klasik dalam penelitian ini meliputi uji normalitas, multikololinieritas, uji heteroskedastisitas dan uji autokorelasi. Hasil asumsi klasik dapat dilihat pada Tabel 5.

Tabel 5.

Hasil Uji Asumsi Klasik

\begin{tabular}{|c|c|c|c|c|c|}
\hline \multirow{2}{*}{$\begin{array}{c}\text { Parameter yang } \\
\text { Diuji }\end{array}$} & \multirow{2}{*}{$\begin{array}{c}\text { UjiNomalita } \\
\text { s }\end{array}$} & \multicolumn{2}{|c|}{ UjiMultikolonieritas } & \multirow{2}{*}{$\begin{array}{c}\begin{array}{c}\text { UjiHeterosk } \\
\text { edastisitas }\end{array} \\
\text { Sig. }\end{array}$} & \multirow{2}{*}{$\begin{array}{c}\begin{array}{c}\text { UjiAutokor } \\
\text { elasi }\end{array} \\
\text { DW }\end{array}$} \\
\hline & & Tolerance & VIF & & \\
\hline $\begin{array}{l}\text { Unstandardized } \\
\text { Residual }\end{array}$ & 0,052 & & & & \\
\hline ROA (X1) & & 0,133 & 7,53 & 0,977 & \\
\hline Size (X2) & & 0,983 & 1,02 & 0,236 & \\
\hline $\begin{array}{l}\text { ROA }(\mathrm{X} 1) * \text { Size } \\
(\mathrm{X} 2)\end{array}$ & & 0,132 & 7,58 & 0,925 & \\
\hline Durbin-Watson & & & & & 2,044 \\
\hline
\end{tabular}

Berdasarkan hasil uji normalitas diperoleh nilai signifikansi sebesar 0,052 yang lebih besar dari level signifikan $(0,052>0,05)$, yang menandakan model yang digunakan sudah berdistribusi normal. Berdasarkan uji multikolonearitas diperoleh nilai tolerance dari setiap variabel lebih besar dari 0,10 dan VIF lebih kecil dari 10, hal ini menunjukkan bahwa tidak terjadi multikolinieritas antara kedua variabel bebas dan menggambarkan asumsi multikolinieritas terpenuhi. Berdasarkan uji heteroskedastisitas diperoleh nilai signifikansi setiap variabel lebih besari dari 0,05 , hal ini menunjukkan bahwa tidak terjadi heteroskedastisitas pada data penelitian yang digunakan. Berdasarkan uji autokorelasi diperoleh nilai DW sebesar 2,044. Nilai dU yang diperoleh untuk penelitian dengan jumlah sampel $(\mathrm{N})$ sebanyak 75 dengan jumlah variabel bebas $(\mathrm{k})$ sebanyak 2 adalah 
sebesar 1,6802, maka nilai $4<\mathrm{dU}$ yang di dapat adalah 2,3198. Hasil uji autokorelasi adalah dU $<$ DW $<4-$ dU yaitu $1,6802<2,044<2,3198$. Dari hasil yang telah diperoleh maka dapat disimpulkan bahwa model regresi yang digunakan bebas dari autokorelasi.

Tabel 6.

Hasil Uji Moderating Regression Analysis

\begin{tabular}{|c|c|c|c|c|c|c|}
\hline \multirow{2}{*}{ Model } & \multicolumn{2}{|c|}{$\begin{array}{c}\text { Unstandardized } \\
\text { Coefficients }\end{array}$} & \multirow{2}{*}{$\begin{array}{c}\begin{array}{c}\text { Standardized } \\
\text { Coefficients }\end{array} \\
\text { Beta }\end{array}$} & \multirow{2}{*}{$t$} & \multirow{2}{*}{ Sig. } & \multirow{2}{*}{ HasilUjiHipotesis } \\
\hline & $\boldsymbol{B}$ & $\begin{array}{c}\text { Std. } \\
\text { Error }\end{array}$ & & & & \\
\hline (Constant) & $-0,040$ & 0,068 & & $-0,589$ & 0,552 & \\
\hline ROA (X1) & $-0,185$ & 0,032 & $-1,400$ & $-5,839$ & 0,000 & H1 Diterima \\
\hline SIZE (X2) & $-0,007$ & 0,008 & $-0,086$ & $-0,971$ & 0,334 & \\
\hline ROA*SIZE(X2X2) & 0,067 & 0,019 & 0,869 & 3,615 & 0,001 & H2 Ditolak \\
\hline $\mathrm{R}$ & 0,667 & & & & & \\
\hline$R$ Square & 0,458 & & & & & \\
\hline Adjusted R Square & 0,453 & & & & & \\
\hline F Hitung & 20,018 & & & & & \\
\hline Sig. F & 0,000 & & & & & \\
\hline
\end{tabular}

Berdasarkan Tabel maka dapat dibuat persamaan regresi linier moderasi sebagai berikut:

$$
Y=-0,040-0,185 X_{1}-0,007 X_{2}+0,067\left(X_{1} X_{2}\right)+\varepsilon
$$

Nilai konstan sebesar -0,040 memiliki makna bahwa jika nilai dari variabel independen (profitabilitas dan ukuran perusahaan) tidak ada atau bernilai 0 , maka persentase ETR akan berkurang sebesar 0,040 atau sama dengam besarnya tingkat penghindaraan pajak sebesar 0,040 . Nilai koefisien $\left(\beta_{1}\right)$ sebesar $-0,185$ menandakan bahwa jika ROA mengalami peningkatan sebesar $1 \%$ maka akan terjadi penurunan ETR sebesar 0,185 atau meningkatnya praktik penghindaran pajak yang dilakukan perusahaan sebesar 0.185 dengan asumsi variabel 
independen lainnya konstan. Nilai koefisien $\left(\beta_{2}\right)$ sebesar $-0,007$ mengartikan bahwa jika ukuran perusahaan meningkat $1 \%$ maka akan terjadi penurunan ETR sebesar 0,007 atau meningkatnya tingkat penghindaran pajak yang dilakukan perusahaan sebesar 0,007 dengan asumsi variabel independen lainnya konstan. Nilai koefisien $\left(\beta_{3}\right)$ sebesar 0,064 menunjukkan bahwa apabila interaksi antara ROA dengan ukuran perusahaan meningkat satu satuan, maka terjadi peningkatan ETR sebesar 0,064 atau tingkat penghindaran pajak yang dilakukan perusahaan mengalami penurunan sebesar 0,064 dengan asumsi variabel lainnya konstan.

Hipotesis pertama $\left(\mathrm{H}_{1}\right)$ tentang profitabilitas memiliki pengaruh pada Penghindaran Pajak bahwa semakin tinggi rasio profitabilitas dapat meningkatkan praktik penghindaran pajak yang dilakukan perusahaan. Penghindaran pajak diukur dengan ETR, ETR berbanding terbalik dengan penghindaran pajak, semakin kecil persentase ETR maka semakin besar penghindaran pajak yang dilakukan perusahaan. Berdasarkan analisis regresi moderasi diperoleh nilai $\beta_{1}$ sebesar $-0,185$ yang menunjukkan arah negatif pada ETR yang menandakan semakin kuat praktik penghindaran pajak yang dilakukan perusahaan dan nilai signifikansi sebesar 0,000 yang lebih kecil dari $\alpha=0,05$, maka hipotesis pertama $\left(\mathrm{H}_{1}\right)$ diterima. Hal ini berarti profitabilitas berpengaruh positif signifikan pada penghindaran pajak.

Perusahaan yang mempunyai profitabilitas tinggi akan membayar pajak lebih tinggi seiring dengan laba yang diperoleh perusahaan meningkat, maka perusahaan yang memiliki profitabilitas yang tinggi akan cenderung melakukan praktik penghindaran pajak untuk menghindari besarnya beban pajak yang 
ditanggung perusahaan. Perusahaan yang mampu mengelola asetnya dengan baik akan memperoleh keuntungan dari insentif pajak dan kelonggaran pajak lainnya sehingga perusahaan tersebut akan terlihat melakukan praktik penghindaran pajak (Darmawan, 2014). Hasil penelitian ini sejalan dengan penelitian yang telah dilakukan oleh Dewinta (2016), Praditasari (2017), Dewi (2017), dan Darmawan (2014) yang menyatakan bahwa ROA Berpengaruh positif pada penghindaran pajak.

Berdasarkan hasil analisis regresi moderasi pada Tabel 3 menunjukkan nilai $\beta_{3}$ sebesar 0,067 yang menunjukkan bahwa terjadi peningkatan persentase ETR atau menandakan pembayaran pajak yang dilakukan perusahaan mendekati tarif dasar pajak atau menurunkan praktik penghindaran pajak yang dilakukan perusahaan dengan nilai signifikansi sebesar 0,001 lebih kecil dari $\alpha=0,05$, nilai rata ETR pada uji statistik deskriptif juga menunjukkan nilai 0,257 yang sudah sesuai dengan tarif dasar pajak penghasilan badan yang berlaku di Indonesia, hal ini menunjukkan bahwa ukuran perusahaan mampu memperlemah hubungan profitabilitas pada penghindaran pajak. Perusahaan yang berukuran besar cenderung akan mendapat pengawasan dari pemerintah untuk dikenai pembayaran pajak yang sesuai dengan peraturan perpajakan yang berlaku, sehingga perusahaan yang tergolong perusahaan besar cenderung untuk tidak melakukan praktik penghindaran pajak agar terhindar dari sanksi perpajakan. Hasil penelitian ini sejalan dengan penelitian yang telah dilakukan oleh Dewi (2017), Praditasari(2017), dan Sari (2014) yang menunjukkan hasil ukuran perusahaan berpengaruh negatif pada penghindaran pajak. 
Jenis moderasi dalam hipotesis ini dapat dilihat pada Tabel 3 yaitu tingkat signifikansi $X_{2}$ lebih besar dari 0,05 maka $\beta_{2}$ tidak signifikan dan $\beta_{3}$ lebih kecil dari 0,05 maka $\beta_{3}$ signifikan. Oleh karena $\beta_{2}$ tidak signifikan dan $\beta_{3}$ signifikan maka jenis moderasi dalam hipotesis ini yaitu pure moderasi (moderasi murni), dimana variabel moderator tidak berhubungan dengan variabel dependen dan/atau independen, namun berinteraksi dengan variabel independen.

\section{SIMPULAN}

Berdasarkan pada hasil analisis dan pembahasan pada hasil penelitian ini dapat ditarik kesimpulan bahwa variabel profitabilitas yang diukur dengan menggunakan Return On Assets berpengaruh positif pada penghindaran pajak. Laba besar yang diperoleh perusahaan akan menyebabkan beban pajak penghasilan yang ditanggung perusahaan akan membesar, sehingga perusahaan cenderung akan melakukan penghindaran pajak untuk menghindari pembayaran pajak yang besar. Semakin tinggi rasio ROA suatu perusahaan maka semakin tinggi praktik penghindaran pajak yang dilakukan perusahaan.

Berdasarkan penelitian yang telah dilakukan, hasil analisis menunjukkan interaksi antara profitabilitas dengan ukuran perusahaan akan menyebabkan tingkat penghindaran pajak yang dilakukan perusahaan akan menurun. Perusahaan yang tergolong kategori perusahaan besar akan mendapatkan perhatian lebih dari pemeritah terhadap kinerja manajemen perusahaan sehingga praktik penghindaran pajak yang dilakukan perusahaan akan semakin menurun.

Saran yang bisa diberikan bagi perusahaan agar dapat memperhatikan setiap keputusan yang akan dilakukan serta risiko yang akan ditanggung dari 
setiap keputusan yang dibuat apakah sudah sesuai dengan undang-undang dan peraturan perpajakan yang berlaku. Dilihat dari ukuran rata-rata perusahaan yang cenderung lebih mendekati nilai maksimal sehingga menyebabkan perusahaan cenderung lebih diawasi oleh pemerintah dalam hal penerimaan pajak. Bagi pemerintah diharapkan dapat meningkatkan pengawasan yang lebih teliti terhadap pajak yang dibayarkan perusahaan sehingga dapat meningkatkan penerimaan pajak negara dan mengurangi praktik penghindaran pajak yang dilakukan perusahaan.

\section{REFERENSI}

Agusti, Wirna Yola dan Efrizal Syofyan. 2014. Pengaruh Profitabilitas, Leverage, dan Corporate Governance Terhadap Tax Avoidance. Skripsi Program Sarjana Fakultas Ekonomi Universitas Padang, Padang.

Cahyono, Deddy Dyas, Rita Andini dan Kharis Raharjo. 2016. Pengaruh Komite Audit, Kepemilikan Institusional, Dewan Komisaris, Ukuran Perusahaan (Zise), Leverage (DER) dan Profiabilitas (ROA) terhadap Tindakan Penghindaran Pajak (Tax Avoidance) pada Perusahaan Perbankan yang Listing di BEI Periode Tahun 2011-2013. Jurnal Akuntansi Universitas Pandanaran, 2 (2).

Darmadi, Iqbal Nul Hakim. 2013. Analisis Faktor yang Mempengaruhi Manajemen Pajak dengan Indikator Tarif Pajak Efektif. Skripsi Program Sarjana Fakultas Ekonomika dan Bisnis Universitas Diponogoro, Semarang.

Darmawan, I Gede Hendy dan I Made Sukartha. 2014. Pengaruh Penerapan Corporate Governance, Leverage, Return on Assets, dan Ukuran Perusahaan pada Penghindaran Pajak. E-Jurnal Akuntansi Universitas Udayana, 9 (1), Hal. 143-161.

Dewi, Ni Luh Putu Puspita dan Naniek Noviari. 2017. Pengaruh Ukuran Perusahaan, Leverage, Profitabilitas, dan Corporate Social Responsibility Terhadap Penghindaran pajak (Tax Avoidance). E-Jurnal Akuntansi Universitas Udayana, 21 (1), Hal. 830-859.

Dewinta, Ida Ayu Rosa dan Putu Ery Setiawan. 2016. Pengaruh Ukuran Perusahaan, Umur Perusahaan, Profitabilitas, Leverage, dan Pertumbuhan 
Penjualan Terhadap Tax Avoidance. Skripsi Sarjana Jurusan Akuntansi pada Fakultas Ekonomi dan Bisnis Universitas Udayana, Bali

Dewinta, Ida Ayu Rosa dan Putu Ery Setiawan. 2016. Pengaruh Ukuran Perusahaan, Umur Perusahaan, Profitabilitas, Leverage, dan Pertumbuhan Penjualan Terhadap Tax Avoidance. E-Jurnal Akuntansi Universitas Udayana, 14 (3), hal.1584-1613.

Dharma, I Made Surya dan Putu Agus Ardiana. 2016. Pengaruh Leverage, Intensitas Aset Tetap, dan Koneksi Politik Terhadap Tax Avoidance. EJurnal Akuntansi Universitas Udayana, 15 (1), hal.584-613.

Frank, M., Lynch, L., danRego, S. 2009. Tax reporting aggressiveness and its relation to aggressivefinancial reporting. The Accounting Review.

Hanlon, M. and S. Heitzman. 2010. A Review Of Tax Research. Juournal of Accounting and Economics, 50: h: 127-178.

Ilyas, W \&amp; Burton,R. 2013. Hukum Pajak. Edisi 6. Jakarta: Salemba.

Jacob, Fatoki Obafemi FCA. 2014. An Empirical Study of Tax Evasion and TaxAvoidance: A Critical Issue in Nigeria Economic Development. Journal of Economics and Sustainable Development, 5(18), pp: 22-27.

Jensen, Michael C and Willliam H. Meckling. 1976. Theory of the Firm: Managerial Behavior. Agency Cost and Ownership Structure. Journal of Financial Economic, Vol 3, No 4.

Kirchler E, Maciejovsky B, Schneider F. 2002. Everyday representations of tax avoidance, tax evasion, and tax flight: Do legal differences matter?, Journal of Economics Psycology (2003). Vol. 24, Pages. 535-553.

Liputan6.com. 2017. Penerimaan Pajak Capai 81 Persen dari Target 2016. http://bisnis.liputan6.com/read/2693979/penerimaan-pajak-capai-81persen-dari-target-2016. Diakses 7 Februari 2018.

Maharani, I Gusti Ayu Cahya dan Ketut Alit Suardana. 2014. Pengaruh Corporate Governance, Profitabilitas dan Karakteristik Eksekutif pada Tax Avoidance. E-Jurnal Akuntansi Universitas Udayana, 9 (2), hal.525-539.

Marfu'ah, Laila, M. Abdul Aris dan Eny Kusumawati. 2015. Pengaruh Return on Assets, Leverage, Ukuran Perusahaan, Kompensasi Rugi Fiskal dan Koneksi Politik Terhadap Tax Avoidance. Naskah Publikasi Jurusan Akuntansi Universitas Muhammadiyah Surakartha. 
Mulyani, S., Darminto., dan Endang, M.W. 2014. Pengaruh Karakteristik Perusahaan, Koneksi Politik dan Reformasi Perpajakan Terhadap Penghindaran Pajak (Studi pada perusahaan manufaktur yeng terdaftar di BEI tahun 2008 - 2012. Jurnal Mahasiswa Perpajakan Universitas Brawijaya, 1 (2),hal.1-9.

Praditasari, Ni Koming Ayu dan Putu Ery Setiawan. 2017. Pengaruh Corporate Governance, Ukuran Perusahaan, Leverage dan Profitabilitas pada Tax Avoidance. E-Jurnal Akuntansi Universitas Udayana, 19 (2), hal.12291258.

Rezika, Mouddy Berlinda. 2017. Pengaruh Mekanisme Corporate Governance dan Profitabilitas terhadap Tax avoidance pada Perusahaan Manufaktur Sub Sektor Makanan dan Minuman yang terdaftar di Bursa Efek Indonesia Tahun 2011-2015. Skripsi Sarjana jurusan Akuntansi fakultas Ekonomi dan Bisnis Universitas Pasundan, Bandung.

Richardson, Grant and R. Lanis. 2007. "Determinants of Variability In Corporate Effective Tax Rates and Tax Reform: Evidence From Australia". Jorunal of Accounting and Public Policy 26 (2007) 689-704.

Saputra, Muhammad Fajri, Dandes Rifa dan Novia Rahmawati. 2015. Pengaruh Corporate Governance, Profitabilitas, dan Karakter Eksekuitif terhadap Tax Avoidance pada Perusahaan yang Terdaftar di BEI. Jurnal Akuntansi Universitas Bung Hatta, 19 (1), Hal. 1-12

Siregar, Rifka dan Dini Widyawati. 2016. Pengaruh Karakteristik Perusahaan Terhadap Penghindaran Pajak pada Perusahaan Manufaktur BEI. Jurnal Ilmu dan Riset Akuntansi Sekolah Tinggi Ilmu Ekonomi Indonesia, 5 (2), Hal. 2460-0585.

Sugiyono, Prof. Dr. 2014. Metode Penelitian Bisnis (Pendekatan Kuantitatif, Kualitatif, dan $R \& D)$. Bandung: Alfabeta.

Sugiyono, Prof. Dr. 2016. Statistika Untuk Penelitian. Bandung: Alfabeta.

Surbakti, Theresa Adelina Victoria. 2012. Pengaruh Karakteristik Perusahaan dan Reformasi Perpajakan Terhadap Penghindaran Pajak di Perusahaan Industri Manufaktur yang Terdaftar di Bursa Efek Indonesia Tahun 20082010. Skripsi Jurusan Akuntansi Fakultas Ekonomi Universitas Indonesia, Jakarta.

Swignly, Calvin dan I Made Sukartha. 2015. Pengaruh Karakter Eksekutif, Komite Audit, Leverage, dan Sales Growth pada Tax Avoidance. E-Jurnal Akuntansi Universitas Udayana, 10 (1), hal.47-62. 
Utami, Nurindah Wahyu. 2012. Pengaruh Struktur Corporate Governance, Size, Profitabilitas Perusahaan terhadap Tax Avoidance. Skripsi Jurusan Akuntansi Fakultas Ekonomi Universitas Sebelas Maret, Surakartha.

Utari, Ni Kadek Yuliani dan Ni Luh Supadmi. 2017. Pengaruh Corporate Governance, Profitabilitas dan Koneksi Politik pada Tax Avoidance. EJurnal Akuntansi Universitas Udayana, 18 (3), hal.2202-2230.

Watts, R.L. dan Zimmerman, J.L. [1986].Positive Accounting Theory. New Jersey: Prentice Hall.

Yogiyanto. 2007. Teori Portofolio dan Analisis Investasi. Yogyakarta: BPFE 